\title{
Escritura en la Redacción Investigativa
}

\author{
PhD. Alba Marina Peña de Salazar \\ Universidad Nacional Experimental de los Llanos Ezequiel Zamora, UNELLEZ \\ albadesalazar@gmail.com \\ Lara, Venezuela
}

\section{Editorial}

Todo proceso investigativo o de investigación requiere de los lineamientos racionales de quien elabora o produce la sistematización de la información del fenómeno que se estudia. Implica materializar a través del escrito no solo su elaboración formal sino la formulación de leyes y construcción de conceptos, modelos y teorías en las que se apoya el trabajo de investigación científica.

El documento e informe final representa el grueso de las ideas o el soporte teórico conceptual de su construcción sistemática durante el recorrido de lo que se investiga, ya sea en el ámbito de las Ciencias Naturales o en el que corresponde a las Ciencias Humanas y Sociales.

Vale la pena reconsiderar en principio, lo tratado por Martínez (2002a): sobre la relación sujeto-objeto como parte del proceso cognitivo desde el punto de vista filosófico y psicológico cuando refiere que "es el sujeto el que da forma y moldea el objeto percibido..." (pág. 89); a través de su lenguaje materializado en el escrito.

Esa misma interacción sujeto-objeto cognitiva afirma que la mente humana construye, como participante activo y formativo de lo que conoce, su objeto, informando por escrito la materia que trata, además de llevar implícita su cultura y el medio donde habita. Ideas de trascendencia que provienen desde el pensamiento de Kant (1786) y que evidencian en la actualidad, la aplicación de la capacidad intelectual lingüística del ser humano a partir de su mundo interior en el contacto con la realidad.

El planteamiento en cuestión responde a la visión específica que tiene 
el hombre para describir o explicar lo que observa según los conocimientos que tiene al respecto y lo que en la práctica produce para escribir.

En consecuencia, el que escribe establece en forma consciente lo que tiene como conocimiento, sentido, estructura y lo que representa, lo que es como sujeto (Valores, intereses, fines, propósitos y temores) para recibir la información que se procesa y que viene desde fuera. Vale decir, ocurre el establecimiento de una interactuación dialéctica cuyo significado se concreta, se altera, se precisa o se complementa en su desarrollo, definitivamente, con el escrito.

Frente a este contexto, el sujeto que investiga se expresa y las oraciones contenidas en el texto, emiten ideas que, en concordancia con los elementos o constructos desarrollados en torno al tema o fenómeno de estudio, están sujetos a limitaciones que las reglas, normas, axiomas, principios o parámetros le exigen en función del tipo de investigación que se asuma.

Un sin número de elementos redaccionales entran en juego cuando a la hora de escribir se deben definir posturas, establecer un norte, decidir por caminos que le permiten al investigador llegar a lo que el estudio pretende como parte de su estructura interna y la que le ofrece el medio para su integración.

Efectos que Martínez (2002b): deduce como una simbiosis entre lo que es ir hacia la objetividad basada en la teoría de lo racional para el logro del todo integrado, coherente y con logicidad.

Tal y como se presenta, la investigación tiene como base el método científico, que pretende un método de estudio. Para ello exige de la aplicación de técnicas, reglas para el razonamiento y la predicción, ideas sobre la experimentación y los modos de comunicar sus resultados. En este sentido se entiende que se rige por formas, elementos, procesos, tipos, que la historia decodifica como el ordenamiento sistémico de normativas de acuerdo con sus 
exigencias en función del propósito o finalidades que se persigan ya sea básica o aplicada.

En resumen, la investigación asume la planificación como proceso de ordenamiento y sistematización de la información, cuenta con el diseño y aplicación de instrumentos, debe caracterizarse por su originalidad, conducida hacia la objetividad evitando las preferencias; elabora análisis, asume los números o realiza mediciones y ofrece resultados comprobables. Pasos que inevitablemente incluyen el pensamiento o tesis del investigador integrando el todo y asumiendo normas procedimentales de escritura en la redacción, a los acordes del buen uso de la gramática del idioma.

Es por ello que, dependiendo de los tipos de investigación aplicados, se sistematiza la información obtenida y, en consecuencia, se redacta el trabajo en atención a las normas establecidas para su escritura y, en general, para su elaboración.

No hay que olvidar que el abordaje de la investigación debe responder a las políticas que en esta materia haya establecido el Estado, la región o a nivel local apuntando a líneas rectoras de investigación en el marco del proceso de desarrollo del país y bajo la dirección de la comunidad académica institucional.

Para escribir el texto es fundamental la aplicación de principios de la redacción científica: precisión, claridad y brevedad del lenguaje, comúnmente orientados desde la redacción básica de la escritura.

La precisión se refiere a la exactitud rigurosa del lenguaje y el estilo cuando se dice lo que se quiere decir. La claridad significa que el lector entiende el mensaje, es decir, que lo decodifica en toda su extensión por cuanto en el lenguaje utilizado utiliza palabras sencillas evitando términos rebuscados. La brevedad alude a la información pertinente comunicándola con el menor uso de palabras. Referencias provenientes de tres autores: Day (2005), de Baiget y Torres (2013), y de Alonso y Piñeiro (2007). 
Coincidencialmente, otros especialistas como Lindsay, Poindron y Morales (2011): plantean tres características importantes de la redacción científica: Claridad, precisión y concisión. Posturas que en términos redaccionales contribuyen significativamente a la afirmación cierta de que escribir se traduce en redactar organizadamente la información mediante el uso de un lenguaje sencillo y entendible. Su función trascendente, dice Carlino (2005): es la de comunicar en forma escrita, lo que se estudia.

Considera que comunicar lo que se pretende con la escritura en investigación es en sí misma, difundir o publicar. Refiere que escribir es empezar a promocionarse teniendo en cuenta si se hace en forma privada 0 pública. Para ello es fundamental que cualquiera sea el texto académico que se escriba, debe cumplir con normas establecidas de estructura y de contenido cuando su propósito sea el de su publicación formal.

Distinguir o atender estructuralmente la escritura y la redacción investigativa según su forma, alude básicamente a la organización del texto en cuanto a hacer uso apropiado del lenguaje con la utilización de un vocabulario técnico, elegante y un estilo sobrio y mesurado. Además, se refiere al uso adecuado de los signos de puntuación, buen uso de las mayúsculas, tipo de letra y consideración de los márgenes.

Por otro lado, vale hacer referencia a las observaciones de fondo en la escritura, en cuanto a mantener la unidad de pensamiento asumiendo la coherencia de las ideas expuestas y la logicidad en el planteamiento desarrollado. Asimismo, es importante lograr la investigación en profundidad, lo cual exige profundidad en la lectura para desarrollar profundidad en el planteamiento o tesis escrita.

Es básica, en este sentido, la originalidad del trabajo en virtud de su escritura y redacción con estilo propio y claro, de manera que sea entendible al lector haciendo uso apropiado de un lenguaje con la sintaxis correcta y la atención al tiempo, al género y al número, que es lo se conoce como 
concordancias.

El escritor debe evitar vicios de la escritura como el queísmo, dequeísmo, repetición de palabras, expresiones innecesarias, anfibologías y cacofonías, que se presentan como errores comunes en los textos escritos de investigación.

Es importante para cerrar, hacer alusión a otro error común que es necesario atender cuando se trata de la escritura: el uso de los tiempos verbales en el contexto de la investigación. La profesora Santalla (2003): ofrece como aporte para la presentación del trabajo y uso de estos tiempos verbales, sin llegar a ser determinante, la siguiente estructura: Escribir en Presente: la Introducción, el Problema, el Marco Teórico, el Tipo de Investigación y las Conclusiones. Escribir en Pasado: el Resumen, el Método, el Análisis y los Resultados y en Futuro: el Proyecto de Investigación. Valdría la pena en este sentido, hacer una reflexión colectiva sobre este aspecto de tal forma que permita a la comunidad académica llegar a acuerdos y asumir la direccionalidad en los procesos de presentación escrita del informe.

Dilucidar sobre la escritura en la redacción investigativa evitaría una titulación poco clara, un inadecuado ordenamiento del texto en general, pobreza y excesos en el uso de palabras en el escrito, una falta de profundidad en el planteamiento general del fenómeno que se estudia y el desconocimiento de normas sobre el discurso y las disposiciones establecidas para tales efectos además de las inconsistencias en ortografía y redacción en cada parte del trabajo.

Palabras clave: escritura; investigación; editorial. 


\section{Writing in the Investigative Writing}

Editorial

Every research or research process requires the rational guidelines of the person who prepares or produces the systematization of the information of the phenomenon being studied. It implies materializing through writing not only its formal elaboration but also the formulation of laws and construction of concepts, models and theories on which scientific research work is based.

The final document and report represents the bulk of the ideas or the conceptual theoretical support of its systematic construction during the course of what is being researched, whether in the field of Natural Sciences or in which it corresponds to the Humanities and Social Sciences.

It is worth reconsidering in principle what Martínez (2002a) has dealt with: the subject-object relationship as part of the cognitive process from the philosophical and psychological point of view when he says that "it is the subject who shapes and shapes the perceived object ... "(page 89); through its language materialized in the writing.

That same cognitive subject-object interaction affirms that the human mind constructs, as an active and formative participant of what it knows, its object, informing in writing the matter it deals with, as well as implying its culture and the environment in which it lives. Ideas of transcendence that come from the thought of Kant (1786) and that evidence at present, the application of the linguistic intellectual capacity of the human being from his inner world in contact with reality.

The approach in question responds to the specific vision that man has to describe or explain what he observes according to the knowledge he has about it and what he produces in practice to write.

Consequently, the writer consciously establishes what he has as knowledge, meaning, structure and what he represents, what he is as a subject 
(values, interests, goals, purposes and fears) to receive the information that is processed and that comes from outside. That is to say, the establishment of a dialectical interaction whose meaning is concrete, altered, precise or complemented in its development, definitely, with the writing occurs.

Faced with this context, the subject who investigates expresses himself and the sentences contained in the text, emit ideas that, in accordance with the elements or constructs developed around the topic or phenomenon of study, are subject to limitations that the rules, norms, axioms, principles or parameters require depending on the type of research that is assumed.

A number of editorial elements come into play when writing should define positions, establish a north, decide on ways that allow the researcher to reach what the study intends as part of its internal structure and the one that offers the means for their integration.

Effects that Martínez (2002b) deduces as a symbiosis between what it is to go towards objectivity based on the theory of the rational for the achievement of the integrated whole, coherent and with logic.

As presented, the research is based on the scientific method, which seeks a method of study. For this, it requires the application of techniques, rules for reasoning and prediction, ideas about experimentation and ways to communicate their results. In this sense it is understood that it is governed by forms, elements, processes, types, that history decodes as the systemic ordering of regulations according to their requirements according to the purpose or purposes pursued, whether basic or applied.

In summary, research assumes planning as a process of ordering and systematizing information, has the design and application of instruments, must be characterized by its originality, driven towards objectivity avoiding preferences; elaborates analysis, assumes numbers or makes measurements and offers verifiable results. Steps that inevitably include the thought or thesis of the researcher integrating the whole and assuming procedural rules of 
writing in the writing, to the chords of the good use of the grammar of the language.

That is why, depending on the types of research applied, the information obtained is systematized and, consequently, the work is written according to the rules established for its writing and, in general, for its preparation.

It should not be forgotten that the approach to research must respond to the policies established in this area by the State, the region or at the local level, pointing to guidelines for research within the framework of the country's development process and under the direction of the institutional academic community.

In order to write the text, the application of principles of scientific writing is fundamental: accuracy, clarity and brevity of the language, commonly oriented from the basic writing of the writing.

Precision refers to the rigorous accuracy of language and style when saying what is meant. Clarity means that the reader understands the message, that is, decodes it in its entirety because in the language used it uses simple words avoiding elaborate terms. Brevity refers to the pertinent information communicating it with the least use of words. References from three authors: Day (2005), Baiget and Torres (2013), and Alonso and Piñeiro (2007).

Coincidentally, other specialists such as Lindsay, Poindron and Morales (2011): pose three important characteristics of scientific writing: Clarity, precision and conciseness. Positions that in editorial terms contribute significantly to the certain affirmation that writing translates into an organized writing of information through the use of simple and understandable language. Its transcendent function, says Carlino (2005): is to communicate in written form, what is studied.

Considers that communicating what is intended with writing in research is in itself, disseminate or publish. Refers that writing is starting to promote taking into account whether it is done privately or publicly. For this it is 
fundamental that whatever academic text is written, it must comply with established rules of structure and content when its purpose is that of its formal publication.

Distinguishing or structurally attending the writing and the investigative writing according to its form, basically alludes to the organization of the text in terms of making appropriate use of the language with the use of a technical, elegant vocabulary and a sober and measured style. In addition, it refers to the proper use of punctuation marks, good use of capitals, type of letter and consideration of margins.

On the other hand, it is worth referring to the background observations in writing, in terms of maintaining the unit of thought assuming the coherence of the ideas presented and the logic in the approach developed. It is also important to achieve in-depth research, which requires depth in reading to develop depth in the approach or written thesis.

It is basic, in this sense, the originality of the work by virtue of its writing and writing with its own style and clear, so that it is understandable to the reader making appropriate use of a language with correct syntax and attention to time, gender and to the number, which is known as concordances.

The writer must avoid defects of writing such as queism, dequeism, repetition of words, unnecessary expressions, amphibologies and cacophonies, which are presented as common mistakes in written research texts.

It is important to close, to allude to another common error that needs to be addressed when it comes to writing: the use of tenses in the context of research. Professor Santalla (2003): offers as a contribution to the presentation of the work and use of these verb tenses, without becoming determinant, the following structure: Write in Present: Introduction, Problem, Theoretical Framework, Research Type and the Conclusions. Write in Past: the Summary, the Method, the Analysis and the Results and in the Future: the Research 
Project. It would be worthwhile in this sense, to make a collective reflection on this aspect in such a way that it allows the academic community to reach agreements and assume the directionality in the processes of written presentation of the report.

To elucidate on the writing in the investigative writing would avoid an unclear degree, an inadequate ordering of the text in general, poverty and excesses in the use of words in the writing, a lack of depth in the general approach of the phenomenon that is studied and the ignorance of norms on the speech and the dispositions established for such effects in addition to the inconsistencies in spelling and writing in each part of the work.

Keywords: writing; research; publishers. 


\section{Referencias}

Baiget, T., \& Torres, D. (2013). Informe Apei sobre Publicación en revistas científicas. Informe Apei 7. España: Gijón: Asociación Profesional de Especialistas en Información.

Carlino, P. (2006). La escritura en la investigación. Documento de trabajo № 19 Universidad de Buenos Aires. Argentina: Conferencia pronunciada en el Seminario Permanente de Investigación.

Day, R. (2005). ¿Cómo escribir y publicar trabajos científicos? 5a edición. Publicación Científica y Técnica No. 598. Washington DC: The Oryx Press.

Kant, I. (1786). Principios metafísicos de la ciencia de la naturaleza. (Metaphysische Anfangsgründe der Naturwissenschaft). ISBN: 84-2060394-5. Madrid: Trad. de C. Másmela, Alianza Editorial.

Lindsay, D., Poindron, P., \& Morales, T. (2011). Guía de Redacción Científica. México: Editorial Trillas.

Martínez, M. (2002a,b). La nueva ciencia. Su desafío, lógica y método. México: Editorial Trillas.

Santalla, Z. (2003). Guía para la elaboración formal de reportes de investigación. ISBN: 9802440000. Venezuela: Universidad Católica Andrés Bello.

Alonso, M., \& Piñeiro, N. (2007). ¿Cómo escribir un artículo científico? Alcmeon, Revista Argentina de Clínica Neuropsiquiátrica, 14(2), 76-81, ISSN-e: 1514-9862. Recuperado de:

https://www.alcmeon.com.ar/14/54/11 Nereyda.pdf 


\section{PhD. Alba Marina Peña de Salazar \\ e-mail: albadesalazar@gmail.com}

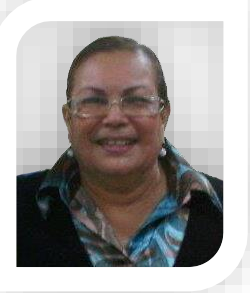

Nacida en Cabimas, estado Zulia, Maracaibo, Venezuela. Postdoctorado en Gestión del Conocimiento (2011-2012); Dra. en Ciencias de la Educación (Universidad Santa María, 2008); MSc. en Planificación y Administración de la Educación (Universidad Simón Rodríguez, 1984); MSc. Administración de la Educación (Instituto Universitario Pedagógico de Caracas, 1979); Lic. en Educación (Universidad de los Andes, 1970); Profesora Emérita de la UNELLEZ; Manual de Trabajo de Grado de la Universidad Fermín Toro (Universidad Fermín Toro, 2009); Métodos y Técnicas de Investigación (UNELLEZ, 2008); Desarrollo del talento humano. (Complejo Educativo Antonio José De Sucre, 2011); Formación de tutores para Trabajo de Grado del programa de Ciencias de la Educación (UNELLEZ, 2012); Socialización filosófica de saberes desde el ser (Universidad Fermín Toro, 2013); Coordinadora General (Universidad Fermín Toro, 2011); Coordinadora Académica Maestría Gerencia y Liderazgo en Educación y Doctorado en Ciencias de la Educación (Universidad Fermín Toro, 20082011); Delegado Vicerrectorado Barinas (Caja de Ahorros de los Profesores CAPROF, 2006-2008); Subdirectora Académica del Instituto Universitario de Tecnología Coronel Agustín Codazzi (IUTAC, 2001-2003); Coordinadora del Convenio UNELLEZ, Zona Educativa y Dirección de educación (UNELLEZ, 1992-2001); Jefe del Programa de Educación Integral (UNELLEZ, 1992); Jefe del Subprograma Campo (UNELLEZ, 1989-1992); Jefe del Proyecto de Formación Social (UNELLEZ, 1988-1989). Participa activamente como coeditora, investigadora y arbitro en la Revista Scientific, ISSN: 2542-2987. 